\title{
Nano-nickel-copper alloy deposit for improved corrosion resistance in marine environment
}

\author{
S. M. Silaimani · G. Vivekanandan • \\ P. Veeramani
}

Received: 2 December 2013/Revised: 11 March 2014/Accepted: 19 April 2014/Published online: 15 May 2014

(C) Islamic Azad University (IAU) 2014

\begin{abstract}
The nickel-copper alloy (70:30) prepared by metallurgical route is currently employed in marine environments because of its good resistance to corrosion. This alloy forms a thin protective surface layer when exposed to marine atmosphere and thus provides its corrosion resistance. Electrodeposition of nickel-copper alloy from sulphamate acetate-based electrolyte is a new and novel approach and was experimented. The detailed study was performed on the effect of electrolyte composition, current density and $\mathrm{pH}$ on the preparation of alloy deposit; the prepared alloy deposit particle size is of $78 \mathrm{~nm}$, and the surface morphology of the alloy deposit was characterized with X-ray diffraction, scanning electron microscopy, EDAX, and atomic force microscope. Nickel-copper alloy deposited from the sulphamate acetate-based electrolyte operated at a temperature of $30{ }^{\circ} \mathrm{C}$, with a pH of 6.6 and at $3 \mathrm{~A} / \mathrm{dm}^{2}$, produces nickelcopper (70:30) alloy deposit. The corrosion behaviour of this alloy deposit was studied by potentiodynamic polarization method; the corrosion current of nickel is $8.67 \mu \mathrm{A} \mathrm{cm}^{-2}$ and the nickel-copper alloy is $2.65 \mu \mathrm{A} \mathrm{cm}{ }^{-2}$.
\end{abstract}

Keywords Nickel-copper alloy deposition · Nanonickel-copper alloy coating - Corrosion protection alloy . Marine protection coating

\section{Introduction}

Electrodeposited alloys are gaining importance than wrought metal alloys produced either by molten technique

S. M. Silaimani $(\varangle) \cdot$ G. Vivekanandan · P. Veeramani

Industrial Metal Finishing Division, CSIR-Central

Electrochemical Research Institute, Karaikudi 630006,

Tamilnadu, India

e-mail: silaimani65@rediffmail.com or other techniques such as doping or mixing powders because of possessing improved chemical and mechanical properties. Because of industrial developments, the installed steel structures are to be protected even in severe marine conditions; for this conventional deposition of single metal does not serve the purpose, somehow bimetallic alloy deposit does the purpose. Electrodeposition of nickel-copper alloy is known for its good and improved corrosion protection for the steel structural's in marine atmosphere. Even though conventional nickel-copper alloy, i.e. monel metal, is familiar for coinage, corrosion protection, and filament for electrical heaters, this electrodeposited alloy finds wide usage in marine structures, oil refineries, oil wells located in mid-sea, and rocket launch platforms located near sea.

Falke et al. (1979) developed the nickel-copper alloy deposit from acetate bath. Bradley et al. (1996) studied the nickel-copper alloy deposit from sulphamate electrolyte; Vu Quang et al. (1985) and Abd El Rehim et al. (1999) investigated the electrodeposition of nickel-copper alloy from citrate-based formulation and studied the effects of current, agitation, and temperature. Green et al. (1998) also investigated the stability of citrate electrolyte and the effect of $\mathrm{pH}$ on alloy deposition. Dube et al. (1995) made a detailed study on electroreduction of heterotetranuclear complexes during alloy deposition. Chassaing and Vu Quang (1987) studied the co-deposition kinetics of nickel-copper alloy in complexing citrate ammonia electrolyte. Horkans et al. (1991) explained the usage of rotating disc electrode and the effect of nickelcopper alloy deposits. Ishikawa et al. (1995) informed the deposition process from pyrophosphate-based electrolyte and studied the effects of bath composition and operating conditions of pyrophosphate tetraborate-based electrolyte on nickel-copper alloy deposition. Sobha et al. (1996) 
studied the electrolyte with hull cell studies and other parameters. Mizushima et al. (1996) used glycine as a complexing agent for the electrodeposited nickel-copper alloy. Cherkaoui et al. (1988) and Roy and Landolt (1995) explained the effect of pulse plating parameters on nickel-copper alloy coating. Toth-Kadar et al. (2000) experimented galvanostatic deposition to produce nickelcopper alloy deposit multilayer by employing DC and pulse current. Alper et al. (2004) discussed the preparation and characterization of nickel-copper alloy multilayers and studied the effect of copper in the deposit with respect to giant magneto resistance (GMR). Ismail et al. (2004) investigated electrochemical behaviour of nickelcopper alloy deposit with different nickel content in sulphamate electrolyte. Priscott et al. (Priscott 1958) and Ogden (1986) informed the preparation of alloy deposit from citrate electrolyte and its mechanical properties. Baskaran et al. (2006) evaluated the characterization of nano-crystalline $\mathrm{Ni}-\mathrm{Cu}$ alloy by pulse electrodeposition. Ying et al. (1988) developed a mathematical modelling for electrodeposition of nickel-copper alloy from citratebased solution; Podlaha et al. (1994) also developed a mathematical modelling on influence of citrate complex in alloy deposition. Roy et al. (1994), Bonou et al. (1994) and Ghosh et al. (1999) explained the corrosion resistance of the nickel-copper alloy deposited from both DC, pulse and reverse pulse techniques. Mohan and Rajasekaran (2011) studied the influence of electrolyte $\mathrm{pH}$ on the composition, corrosion resistance, and morphology of the nickel-copper alloy by brush plating. The present investigation explained about the preparation of nickelcopper alloy deposit from sulphamate acetate electrolyte and the effects of the bath composition, current density, $\mathrm{pH}$, and temperature on the cathodic current efficiency, surface morphology, and corrosion resistance of the alloy deposit.

\section{Materials and methods}

The electrolyte was initially prepared from the nickel sulphamate formulation that contains nickel sulphamate $100 \mathrm{~g} / \mathrm{l}$, ammonium acetate $150 \mathrm{~g} / \mathrm{l}$, copper concentration 8-16 g/l, and Glue $0.05 \mathrm{~g} / \mathrm{l}$. Mechanically polished brass plates of size $25 \times 75 \mathrm{~mm}$ of thickness $0.8 \mathrm{~mm}$ were used as the cathode and titanium substrate insoluble anode (TSIA) was employed for this study; for salt spray studies, steel panels of $50 \times 75 \mathrm{~mm}$ were employed.

The copper acetate concentration was varied from 8 , 12 , and $16 \mathrm{~g} / 1$ in the prepared electrolyte, and the electrolyte containing $16 \mathrm{~g} / \mathrm{l}$ of copper acetate was chosen for nickel-copper deposition of the desired alloy composition (70:30.) By using this electrolyte (that contains $16 \mathrm{~g} / \mathrm{l}$ of copper acetate), further deposition was carried out at various current densities $1,2,3$, and $4 \mathrm{~A} / \mathrm{dm}^{2}$. Among these, the deposit produced at a current density $3 \mathrm{~A} / \mathrm{dm}^{2}$ is having desired composition with maximum cathode current efficiency; so this current density was fixed for further studies. This alloy deposition was further carried out at various $\mathrm{pH} 4.6,6.6$, and 8 by maintaining the current density at $3 \mathrm{~A} / \mathrm{dm}^{2}$ in the electrolyte. The deposit produced at $\mathrm{pH} 4.6$ and 8 is of good appearance, but the alloy deposition efficiency is of lower value; hence, the $\mathrm{pH}$ of the electrolyte has fixed at 6.6. When the electrolyte temperature is raised from 20 to $30^{\circ} \mathrm{C}$, the cathode current efficiency is increased and further raised to $40{ }^{\circ} \mathrm{C}$, and the fall in current efficiency was noticed. Further at the temperature $40^{\circ} \mathrm{C}$, no alloy deposition is produced, and hence, the temperature is limited at $30{ }^{\circ} \mathrm{C}$ for further studies. The composition of nickel and copper in the alloy is analysed by EDAX and in the electrolyte by AAS Varian Model SpectrAA220.

Surface morphology and the crystal structure

The surface morphology and grain size of the alloy deposits prepared from the electrolyte at various conditions were examined at a magnification $(2000 \mathrm{x})$ by using scanning electron microcopy (SEM) of model S-3000H, HITACHI, JAPAN. X-ray diffraction (XRD) (ModelPW3040/60 X'pert PRO, make-PANalytical, the Netherlands) with copper target radiation was used to understand phase orientation and lattice parameters of the deposit. The particle size of the deposit was calculated from the XRD data using Scherrer formula. The surface morphology of the alloy deposit as well as the particle size of the deposit obtained at the current density of 3 and $4 \mathrm{~A} / \mathrm{dm}^{2}$ was confirmed by atomic force microscope (AFM) (Model Picoscan 2000 Make: Molecular Imaging).

\section{Corrosion studies}

The corrosion resistance of the coating, prepared from the electrolyte that contain various concentration of copper, at different current densities, temperature, and $\mathrm{pH}$ value in $5 \%$ sodium chloride solution was estimated by potentiodynamic polarization method using BAS-IM6 Impedance analyzer. The potentials were scanned over $200 \mathrm{mV}$ in both cathodic and anodic direction from the open circuit potentials using platinum as counter electrode and standard calomel electrode (SCE) as reference electrode. The interception of the linear portion of the two polarization curves offers $\mathbf{I}$ corr and $\mathbf{E}$ corr values. Further, standard panels were coated with this alloy deposit, and salt spray test was carried out as per ASTM B117 and compared with bare nickel deposit. 


\section{Results and discussion}

\section{Effect of variables}

After the preparation of electrolyte, the nickel-copper alloy deposits are prepared on polished brass plates. The foremost importance is given on copper concentration in the deposit as this is the deciding factor of alloy composition. The copper acetate is added to the electrolyte as the copper metal concentration as 8,12 , and $16 \mathrm{~g} / \mathrm{l}$, and the prepared deposits are analysed by employing EDAX. The deposit obtained from the electrolyte that contains $8 \mathrm{~g} / \mathrm{l}$ copper metal produces alloy containing 85.31 and $14.69 \%$ of nickel and copper. Further addition of copper metal as $12 \mathrm{~g} / \mathrm{l}$ yields 80.8 and $19.18 \%$ and $16 \mathrm{~g} / \mathrm{l}$ gives 72.80 and $27.2 \%$ of nickel and copper, respectively, in the deposit. Hence, the deposit obtained from the addition of $16 \mathrm{~g} / \mathrm{l}$ copper in the electrolyte is considered for further experiments as it matches the conventional 70:30 composition of nickel with copper. Wilbert and Lee et al. (1949) patented the electrodeposition of nickel-copper alloy from acetatebased electrolyte. Whereas in the present investigation presented, the nickel-copper alloy coating was prepared from nickel sulphamate- and copper acetate-based electrolyte; insoluble anode was employed for easy maintenance of the electrolyte. Then, the other parameters such as current density, $\mathrm{pH}$, and temperature are also varied by maintaining $16 \mathrm{~g} / \mathrm{l}$ concentration of copper is the electrolyte, and data are given in Table 1.

\section{Surface morphology}

\section{Scanning electron microscope}

The surface morphology of nickel-copper alloy deposits are analysed by SEM and presented in Fig. 2. The SEM figure of alloy deposit produced at $1 \mathrm{~A} / \mathrm{dm}^{2}$ could not be

Table 1 Effect of various parameters with nickel-copper alloy deposit

\begin{tabular}{lllllll}
\hline $\begin{array}{l}\text { S. } \\
\text { No }\end{array}$ & $\begin{array}{l}\text { Current } \\
\text { density } \\
\left(\mathrm{A} / \mathrm{dm}^{2}\right)\end{array}$ & $\mathrm{pH}$ & $\begin{array}{l}\text { Temperature } \\
\left({ }^{\circ} \mathrm{C}\right)\end{array}$ & $\begin{array}{l}\text { Copper } \\
(\%)\end{array}$ & $\begin{array}{l}\text { Nickel } \\
(\%)\end{array}$ & $\begin{array}{l}\text { Alloy } \\
\text { efficiency } \\
(\%)\end{array}$ \\
\hline 1 & 1 & 6.6 & 30 & 61.87 & 38.13 & 82.96 \\
2 & 2 & & & 32.00 & 67.99 & 76.34 \\
3 & 3 & & & 27.20 & 72.80 & 97.34 \\
4 & 4 & & & 21.64 & 78.36 & 87.90 \\
5 & 3 & 4.6 & 30 & 78.23 & 21.77 & 34.04 \\
6 & & 8.0 & & 47.09 & 52.91 & 65.22 \\
7 & 3 & 6.6 & 20 & 40.56 & 59.44 & 80.80 \\
8 & & & 25 & 34.77 & 62.56 & 91.37 \\
\hline
\end{tabular}

produced as it is in the powder form. Fig. 1a represents the deposit prepared at $2 \mathrm{~A} / \mathrm{dm}^{2}$ and predicted the threedimensional growth as the grain size is of lamellar one; Fig. 1b shows the grain refinement has taken place in the deposit that was prepared at $2 \mathrm{~A} / \mathrm{dm}^{2}$ and that fine grain deposit was noticed. Fig. 1c shows further reduction in grain size, but many cracks have been observed which is not suitable for corrosion resistance. Fig. 1d, e shows the hydroxide/oxide deposition has taken place after the initial fine grain deposit and is not desirable for corrosion resistance. From Fig. 1f, g, it was observed that alloy deposit produced at a temperature of $20^{\circ} \mathrm{C}$ is mostly of twodimensional one and further raise in temperature to $25^{\circ} \mathrm{C}$; the growth of the deposit is refined into three-dimensional orientation; however, the nickel content in the deposit linearly goes up with further increase in temperature, and hence, the deposit produced at $30{ }^{\circ} \mathrm{C}$ is taken for further corrosion studies.

\section{$X$-ray diffraction}

The XRD patterns of nickel-copper alloy deposits presented in Fig. 2 are polycrystalline in nature. The pattern $2 \mathrm{~A}$ and $2 \mathrm{~B}$ shows the deposit prepared at current densities of 2 and $3 \mathrm{~A} / \mathrm{dm}^{2}$, in which nickel-copper alloy is predominantly deposited with a particle size $78 \mathrm{~nm}$ with the lattice orientation of [111], whereas from the Fig. 2c, the deposit prepared at a current density of $4 \mathrm{~A} / \mathrm{dm}^{2}$, oxide of nickel-copper alloy is predominantly deposited with a lower particle size $65 \mathrm{~nm}$. In Fig. 2d, the deposit prepared at a $\mathrm{pH}$ of 4.6 also indicated oxide of nickel-copper alloy is predominantly deposited with a particle size $43 \mathrm{~nm}$; then, by raising $\mathrm{pH}$ to 8.0 , the peak of nickel-copper alloy is of [111] orientation of particle size $52 \mathrm{~nm}$, and alloy efficiency is lower. So, the deposit represented by Fig. $2 b$ is suitable for the marine application as the predominant peak is nickel-copper in alloy form as well as the particle nano size.

\section{Atomic force microscope}

Fig. 3a, b clearly confirms the particle size of 78 and $65 \mathrm{~nm}$ as the deposit is prepared at current density of 3 and $4 \mathrm{~A} / \mathrm{dm}^{2}$, which is of coincidence with the XRD results.

\section{Corrosion resistance}

It was observed from Fig. 4a that there is no change in corrosion potential from minus 305 to minus $300 \mathrm{mV}$ as well as corrosion current from 2.81 to $2.65 \mu \mathrm{A} \mathrm{cm} \mathrm{cm}^{-2}$ as the coating is prepared from the current density $2-4 \mathrm{~A} / \mathrm{dm}^{2}$. Fig. $4 \mathrm{~b}$ indicates that as the alloy deposit prepared at $\mathrm{pH}$ 4.6 is mostly of oxides, the corrosion potential (minus 
Fig. 1 SEM image of nickelcopper alloy deposit. a $2 \mathrm{~A} /$ $\mathrm{dm}^{2}$, b $3 \mathrm{~A} / \mathrm{dm}^{2}, \mathrm{pH} 6.6,30^{\circ} \mathrm{C}$, c $4 \mathrm{~A} / \mathrm{dm}^{2}$, d at $\mathrm{pH} 4.6$, e at $\mathrm{pH}$ $8, \mathbf{f} 20^{\circ} \mathrm{C}, \mathbf{g} 25^{\circ} \mathrm{C}$
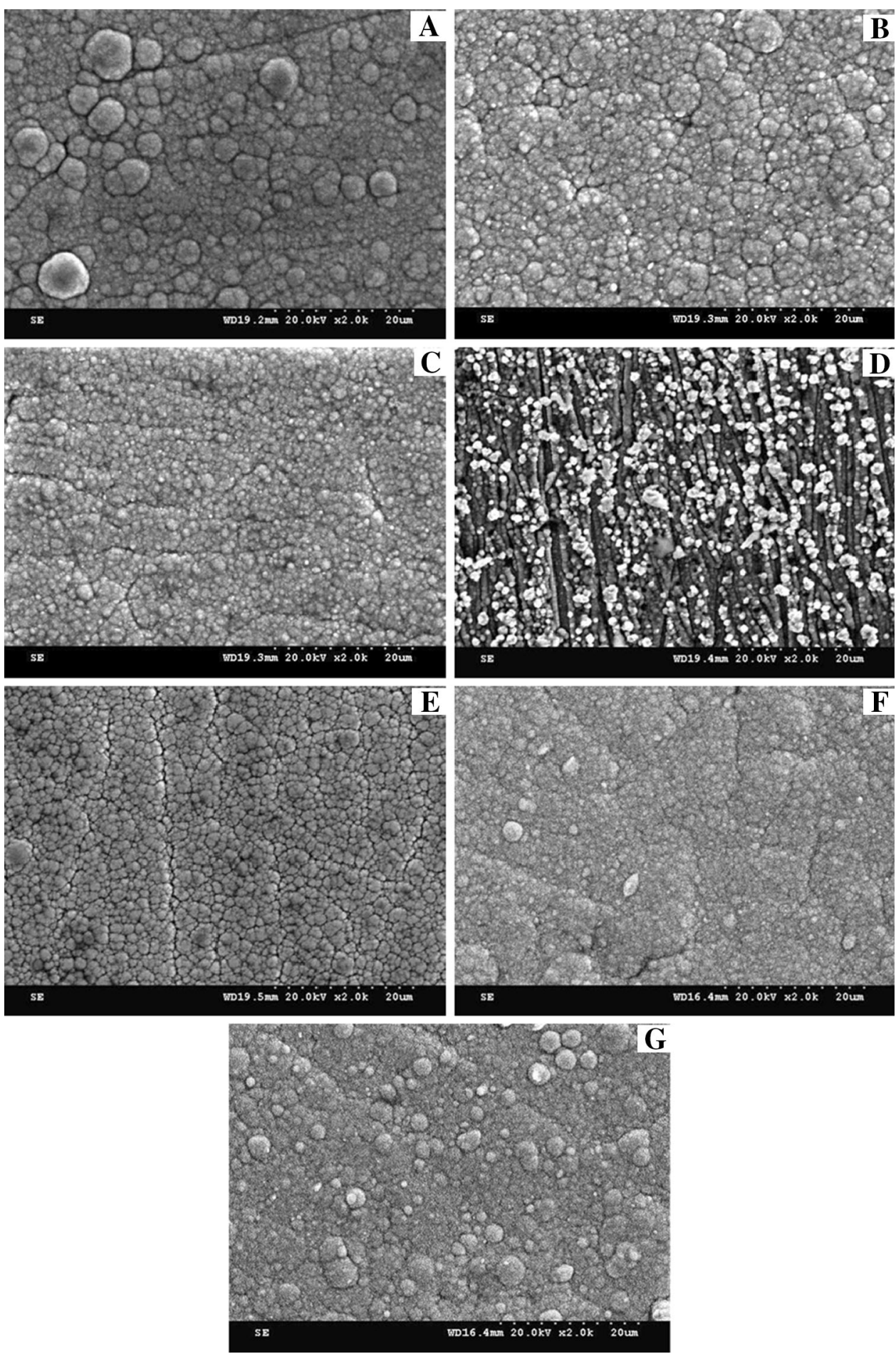

$279 \mathrm{mV}$ ) is in the positive side and current is in higher range $\left(9.7 \mu \mathrm{A} \mathrm{cm}^{-2}\right)$; alloy deposit prepared at $\mathrm{pH} 6.6$ and 8.0 is of alloy form, and the corrosion potential (minus 302 ) is shifted towards negative direction (minus $330 \mathrm{mV}$ ), and the corrosion current is of falling trend $\left(3.0 \mu \mathrm{A} \mathrm{cm} \mathrm{cm}^{-2}\right)$. Fig. $4 \mathrm{c}$ explains the change of two-dimensional growths into three-dimensional growth of the deposit with the enhanced corrosion current of the alloy deposit prepared at 20 and $30^{\circ} \mathrm{C}$. From Fig. $4 \mathrm{~d}$, the corrosion current for nickel deposit alone is $8.67 \mu \mathrm{Acm}^{-2}$, and corrosion potential is minus $504 \mathrm{mV}$ that implies fast dissolution occurs in chlorine or marine atmosphere. But El-sayed sherif et al. (2011) reported the corrosion current 5.6-2.9 $\mu \mathrm{A} \mathrm{cm}{ }^{-2}$, and the corrosion potential from minus 250 to 

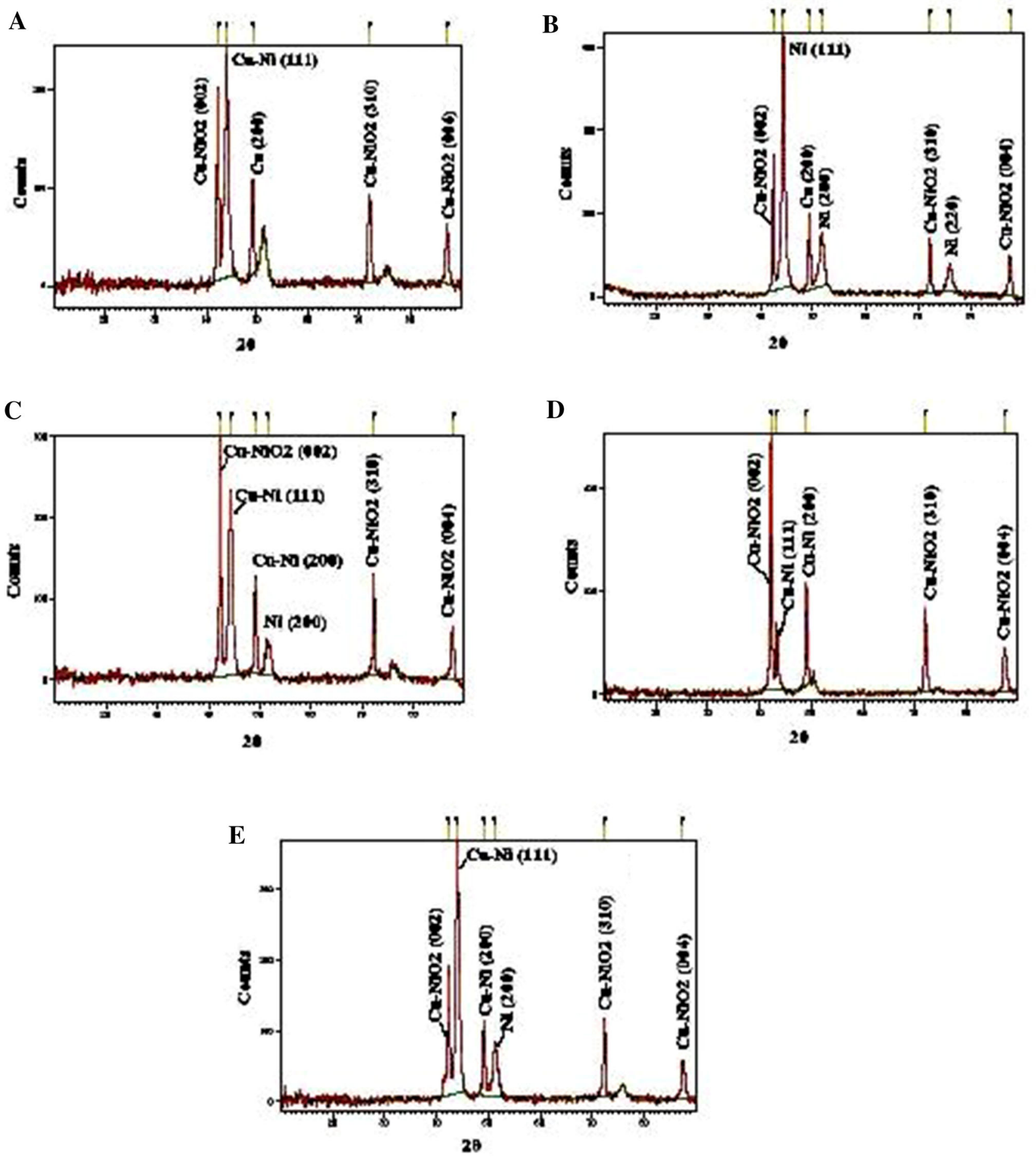

Fig. 2 XRD patterns of nickel-copper alloy deposit. a $2 \mathrm{~A} / \mathrm{dm}^{2}, \mathbf{b} 3 \mathrm{~A} / \mathrm{dm}^{2}, \mathrm{pH} 6.6,30{ }^{\circ} \mathrm{C}, \mathbf{c} 4 \mathrm{~A} / \mathrm{dm}^{2}, \mathbf{d}$ at $\mathrm{pH} 4.6$, e at $\mathrm{pH} 8$

minus $278 \mathrm{mV}$ was reported for conventional nickel-copper alloy of composition 70:30. Hence, this nickel-copper alloy coating is comparable with the conventional alloy.

The nickel-copper alloy and nickel deposit on steel panels were tested in Salt spray chamber that contains
$5 \%$ of sodium chloride solution, and daily visual observation was carried out to notice the brown spot on the coated side. The nickel only deposit withstood only $72 \mathrm{~h}$ (Fig. 5) and nickel-copper alloy deposit panel extended the withstanding period up to $250 \mathrm{~h}$ (Fig. 6). 
Fig. 3 AFM images of nickelcopper alloy deposit.

a $3 \mathrm{~A} / \mathrm{dm}^{2}$, b $4 \mathrm{~A} / \mathrm{dm}^{2}$

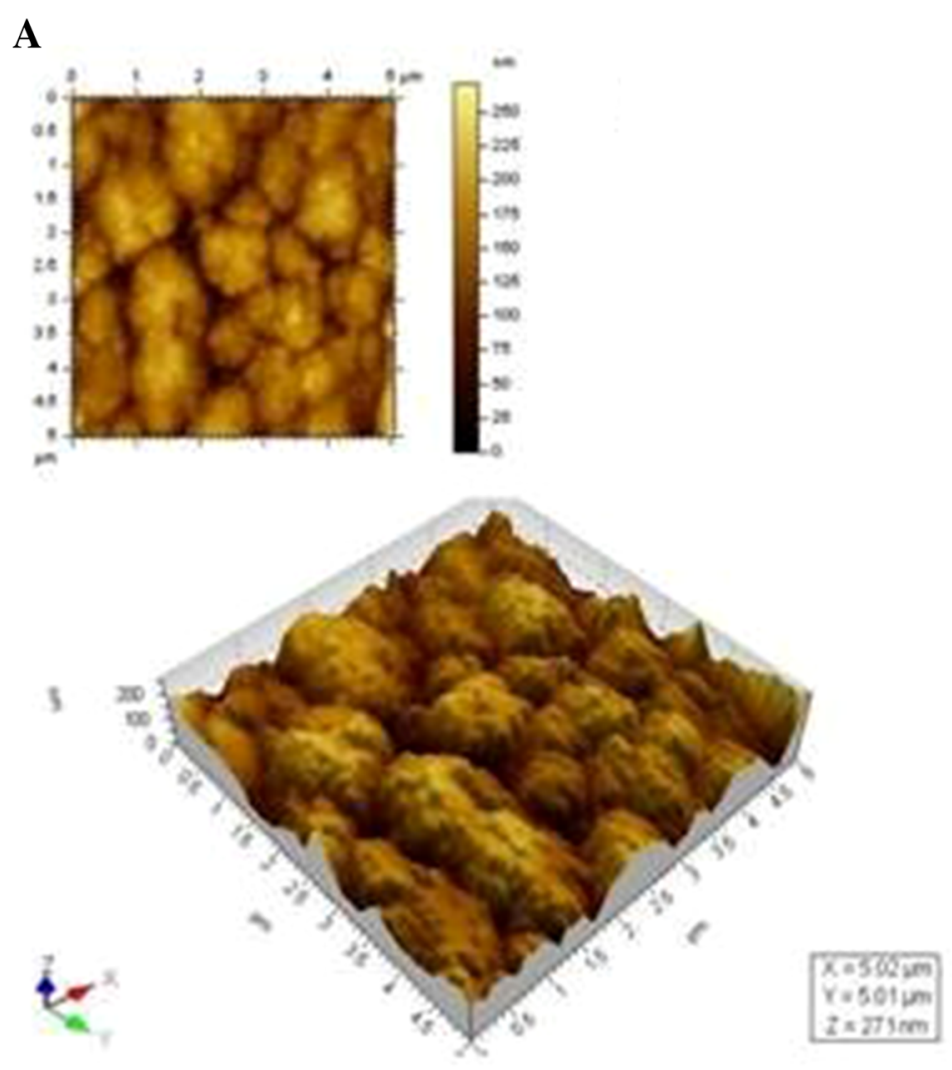

B
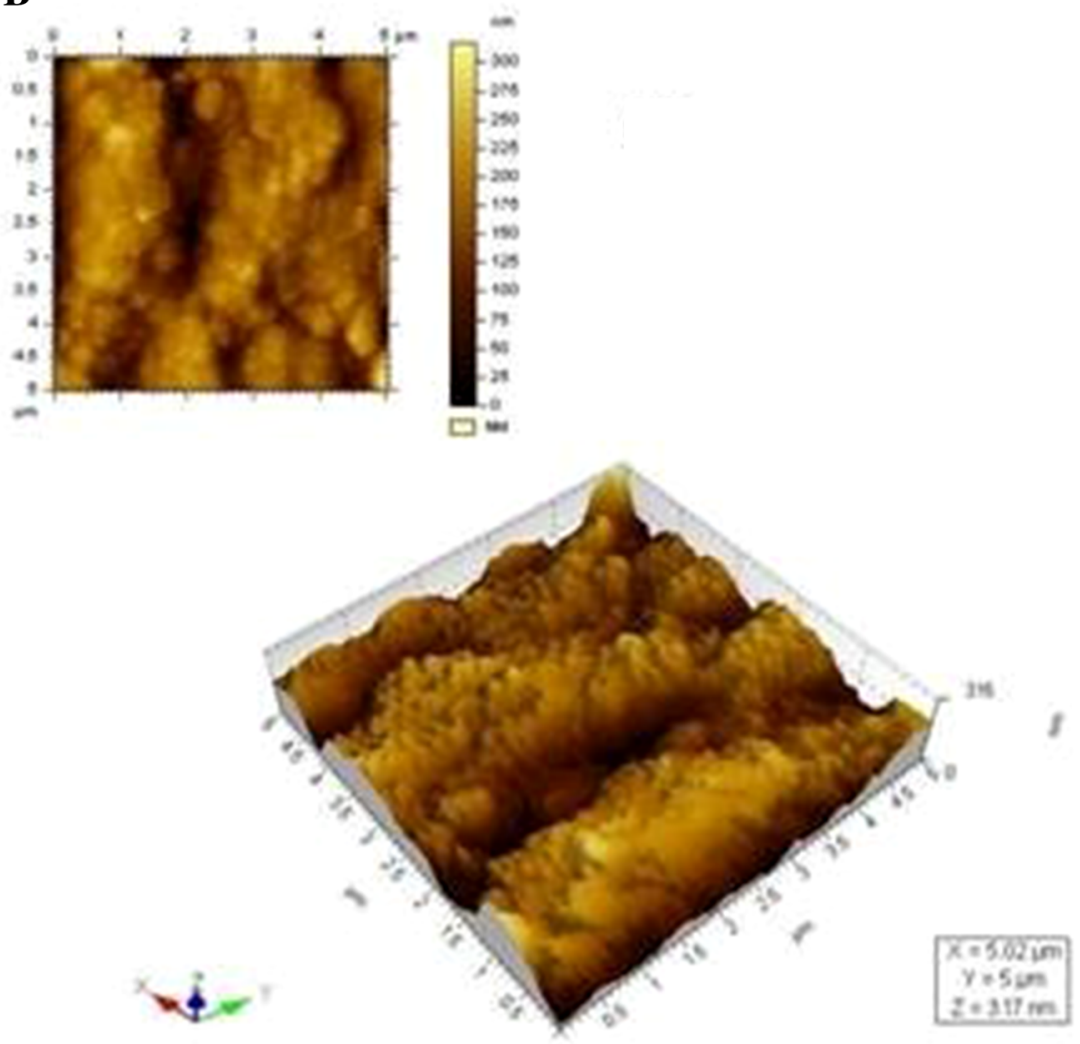

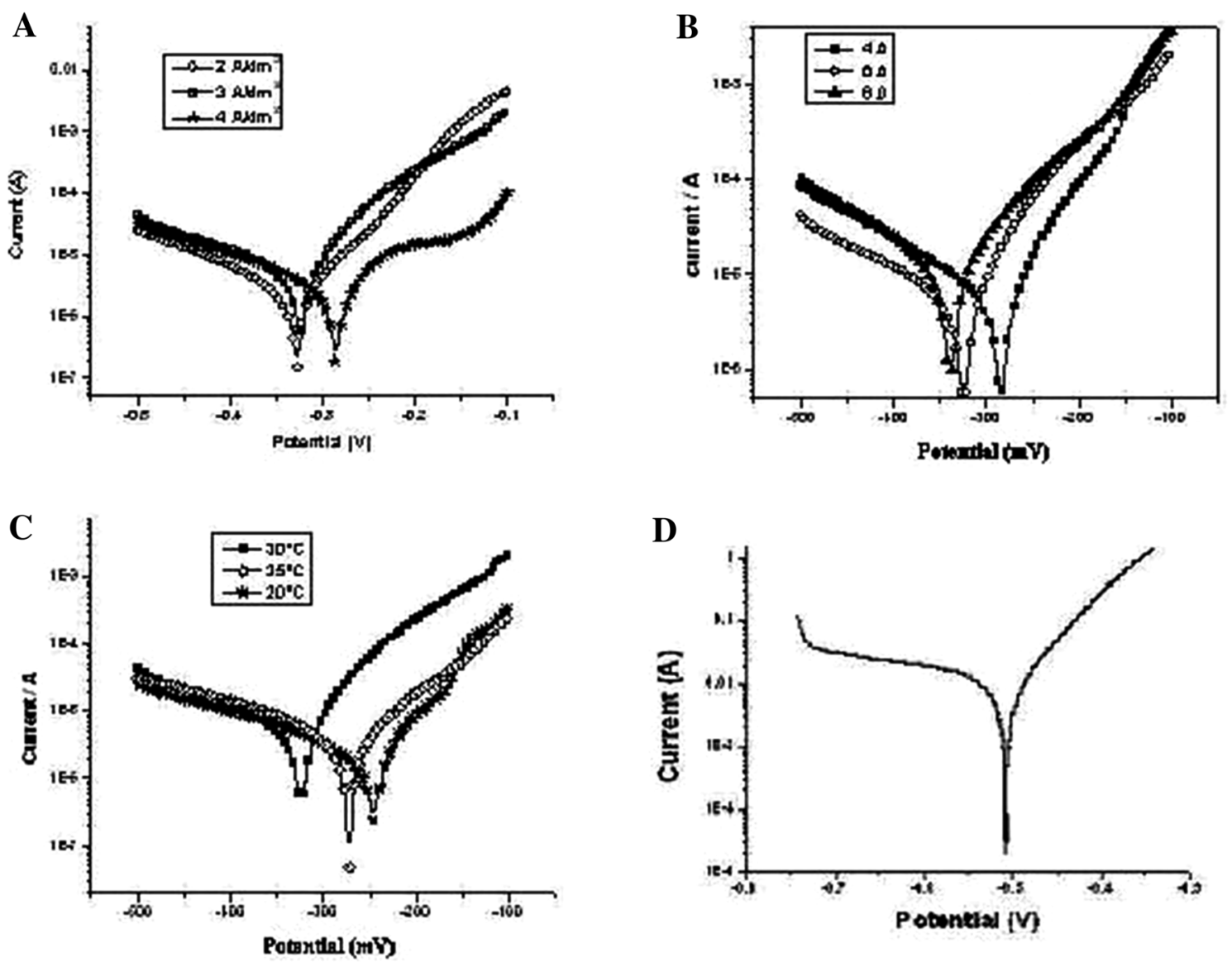

Fig. 4 Corrosion behaviour of nickel-copper alloy deposit a effect of current density $\mathbf{b}$ effect of pH $\mathbf{c}$ effect of temperature d corrosion behaviour of nickel alone deposit

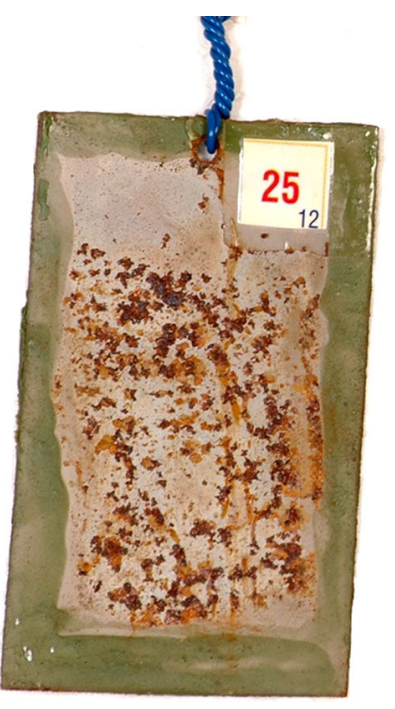

Fig. 5 Salt spray tested nickel deposited panel

This clearly indicated that nickel-copper alloy deposit is having the improved corrosion resistance compared with nickel deposit alone.

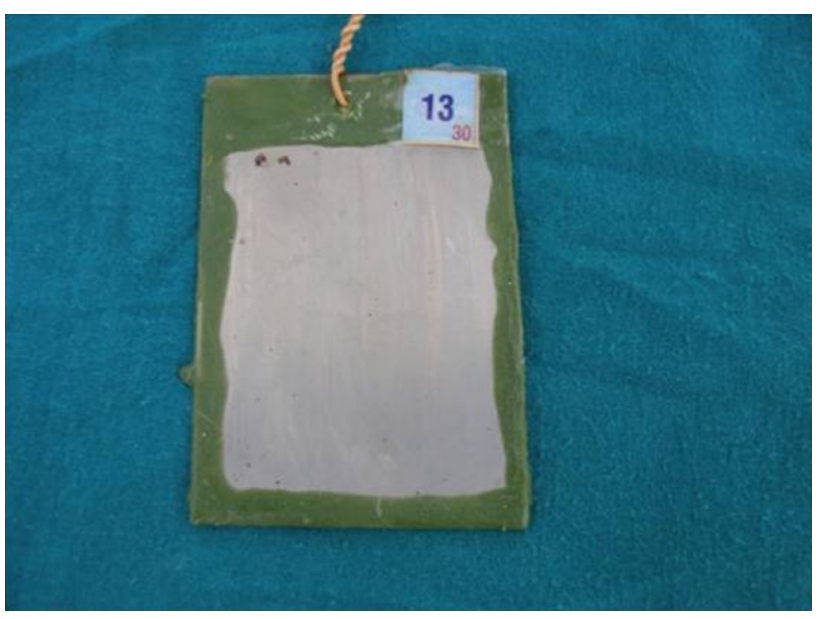

Fig. 6 Salt spray tested nickel-copper alloy deposited panel

\section{Conclusion}

Nickel-copper alloy deposit was effectively prepared from the sulphamate acetate-based electrolyte, was operated at a 
temperature of $30{ }^{\circ} \mathrm{C}$, with a $\mathrm{pH}$ of 6.6 and at a current density of $3 \mathrm{~A} / \mathrm{dm}^{2}$ by employing insoluble anode TSIA, and produces nickel-copper alloy deposit (70:30); it is of metallic in nature with maximum alloy deposition efficiency of $97 \%$. Further, this alloy deposit is of nanocrystalline size of $78 \mathrm{~nm}$ that improves the corrosion resistance than the conventional nickel deposit in the marine atmosphere. Even though corrosion potential of nickel is more cathodic than nickel-copper alloy deposit, the corrosion current for nickel $\left(8.67 \mu \mathrm{A} \mathrm{cm}^{-2}\right)$ is nearly three times higher than nickel-copper alloy $\left(2.65 \mu \mathrm{A} \mathrm{cm}^{-2}\right)$, and the corrosion data of the alloy deposit is comparable with conventional nickel-copper alloy. By performing the salt spray test on these coatings, alloy deposit withstood a longer duration of $250 \mathrm{~h}$ than the nickel deposit $72 \mathrm{~h}$. Hence, this nickel-copper alloy deposit is more suitable for the marine environment.

Acknowledgments Authors are expressing earnest thanks and acknowledge for the funding support of this study to INTELCOATCSC-0114-Council of Scientific and Industrial Research, New Delhi, India.

\section{References}

Abd El Rehim SS, Abd El Wahab S, Rashwan SM, Anwar ZM (1999) Electrodeposition of copper-nickel alloys from a citrate bath containing boric acid. Trans IMF 77(6):242-245

Alper M, Baykul MC, Peter L, Toth J, Bakonyi I (2004) Preparation and characterisation of electrodeposited $\mathrm{Ni}-\mathrm{Cu} / \mathrm{Cu}$ multilayers. J Appl Electrochem 34(8):841-848

Baskaran I, Sankaranarayanan TSN, Stephen A (2006) Pulsed electrodeposition of nano crystalline copper nickel alloy and evaluation of their characteristics. Mater Lett 60:1990-1995

Bonou L, Massiani Y, Crousier J (1994) Electrodeposition and corrosion behavior of copper-nickel alloy. $\mathrm{Br}$ Corros $\mathrm{J}$ 29:201-206

Bradley P, Roy S, Landolt D (1996) Pulse plating of copper-nickel alloys from sulfamate solution. J Chem Soc Faraday Trans 92:4015-4019

Chassaing E, Vu Quang K (1987) Mechanism of copper-nickel alloy electrodeposition. J Appl Electrochem 17:1267-1280

Cherkaoui M, Chassaing E, Vu Quang K (1988) Pulse plating of copper nickel alloy. Surf Coat Technol 34:243-252

Dube CE, Workie B, Kounaves SP, Robbat A Jr, Aksu ML (1995) Electrodeposition of metal alloy and mixed oxide films using a single-precursor tetranuclear copper-nickel complex. J Electrochem Soc 142(10):3357-3365

El-sayed sherif M, Almajid AA, Bairamov AK, Al-Zahrani E (2011) Corroison of Monal-400 in aerated stagnant Arabin gulf seawater after different exposure intervals. Int $\mathrm{J}$ Electrochem Sci 6:5430-5444

Falke WL, Agnes Lee R, Schwaneke AE (1979). Electroplating with $\mathrm{Ni}-\mathrm{Cu}$ alloy US patent., US 4,167,459 A

Ghosh SK, Grover AK, Totlani MK (1999) Nickel-copper alloy electroplating by pulse deposition. Bull Electrochem 15(5-6): 174-178

Green TA, Russell AE, Roy S (1998) The development of a stable citrate electrolyte for the electrodeposition of copper-nickel alloys. J Electrochem Soc 145(3):875-881

Horkans J, Chang ICH, Andricacos PC, Podlaha EJ (1991) Determination of partial currents for $\mathrm{CuNi}$ and $\mathrm{CuCo}$ electrodeposition using rotating ring-disk electrodes. $\mathrm{J}$ Electrochem Soc 138(2):411-416

Ishikawa M, Enomoto H, Matsuoaka M, Iwakura C (1995) Effect of some factors on electrodeposition of nickel copper alloy from pyrophosphate tetra borate baths. Electrochemica Acta 40(11):1663-1668

Ismail KM, Fathi AM, Badawy WA (2004) The influence of Ni content on the stability of copper-nickel alloys in alkaline sulphate solutions. J Appl Electrochem 34(8):823-831

Mizushima L, Chikazawa M, Watanabe T (1996) Microstructure of electrodeposited $\mathrm{Cu}-\mathrm{Ni}$ binary alloy films. J Electrochem Soc 143(6): 1978-1983

Mohan S, Rajasekaran N (2011) Influence of electrolyte $\mathrm{pH}$ on composition of corrosion properties and surface morphology of electrodeposited $\mathrm{Cu}-\mathrm{Ni}$ alloy. Surf Eng 27(7):519-523

Ogden C (1986) High-strength, composite copper-nickel electrodeposits. Plat Surf Finish 73(5):130-134

Podlaha EJ, Bonhote Ch, Landolt D (1994) A Mathematical model and experimental study of the electrodeposition of $\mathrm{Ni}-\mathrm{Cu}$ alloys from complexing electrolytes. Electrochemica Acta 39(18):2649-2657

Priscott BH (1958) Electrodeposition of copper-nickel alloys from citrate solutions. Trans Inst Metal Finish 36:93-96

Roy S, Landolt D (1995) Effect of off-time on the composition of pulse-plated $\mathrm{Cu}-\mathrm{Ni}$ alloys. J Electrochem Soc 142(9):3021-3027

Roy S, Matlosz M, Landolt D (1994) Effect of corrosion on the composition of pulse-plated $\mathrm{Cu}-\mathrm{Ni}$ alloys. J Electrochem Soc 141(6):1509-1517

Sobha J, Krishna N, Sujatha KP, Krishnan RM, Sriveeraraghavan S, Natarajan SR (1996) Electroplating of nickel copper alloys. Bull Electrochem 12:259-265

Toth-Kadar E, Peter L, Becsei T, Toth J, Pogany L, Tarnoczi T, Kamasa P, Bakonyi I, Lang G, Cziraki A, Schwarzacherd W (2000) Preparation and magnetoresistance characteristics of electrodeposited $\mathrm{Ni}-\mathrm{Cu}$ alloys and $\mathrm{Ni}-\mathrm{Cu} / \mathrm{Cu}$ multilayers. J Electrochem Soc 147(9):3311-3318

Vu Quang K, Chassaing E, Le Viet B, Celis JP, Roos JR (1985) Codeposition of nickel and copper. Met Finish 83(10):25-26

Ying RY, Patrick KNg, Mao Z, White RE (1988) Electrodeposition of copper-nickel alloys from citrate solution on rotating disc electrode. J Electrochem Soc 135(12):2964-2971 